\title{
A subordinate standard: Where next?
}

\section{David Fergusson}

The Westminster Confession of Faith (WCF) has been the sole subordinate standard of the Church of Scotland since 1647. Although the formula of subscription signed by ministers and elders has been softened, the Confession holds the same status (hence 'subordinate') beneath the principal standard of the Holy Scriptures.

In what follows, I shall argue the following theses.

1. The Church of Scotland has to a significant extent departed de facto from its subordinate standard over the last three hundred years.

2. A cluster of theological problems surrounding the 1646 document has generated widespread disaffection.

3. Various holding positions were adopted in the late nineteenth century to salve the troubled conscience of the church.

4. These qualifications are largely unsatisfactory and have been recognised as inadequate for a long time.

5. Failure to make progress with the confessional identity of the church in the twentieth century is largely the result of a lack of agreement about what would constitute a better alternative.

6. The task now is to return to this work of revising the confessional standards.

7. Once we reach a more satisfactory alternative, we will be in a better position to appreciate the worth of the WCF.

Adopted by the General Assembly in 1647, the WCF replaced the Scots Confession of 1560 as the church's subordinate standard. It has served several closely related functions.

Kerygmatic - the WCF confesses the faith of the church in a public setting and challenges anyone who dissents from it to show where it deviates from Scripture. 


\section{A subordinate standard}

Didactic - the WCF exercises an important function in the interpretation of Scripture and in guiding ministers, elders and members. Its most important companion document, the Shorter Catechism, was better known throughout the church and continued to be memorised and recited probably until at least the mid1950s. The effect of this long-running practice of catechising is unclear-more research on this subject is needed.

Polemical - the WCF, enabled the church to distance itself from opinions regarded as heterodox or heretical, especially Arminianism and Roman Catholicism. Recent scholarship has pointed to ways in which the minutes of the Assembly reveal anxieties around antinomian trends in Puritan circles. ${ }^{1}$

Disciplinary - the WCF enabled the church to exercise doctrinal discipline on those ordained to office by requiring their subscription and subsequent adherence. Departure from the WCF could constitute grounds for rebuke or removal from office - this was evident in the two famous heresy trials of the nineteenth century featuring John McLeod Campbell and William Robertson Smith.

Political - especially in Scotland, the WCF became the touchstone of Presbyterian orthodoxy against the threat of Episcopalian incursion. The association of Arminianism with Episcopalianism explains in part the hostility to the former. Following the accession of William and Mary in 1689, the WCF would assume a political significance in maintaining the Reformed and Presbyterian identity of the national church north of the border. This is reflected in the stringent formula of 1711 which post-dates the Union of Parliaments and reacts to fears of an imposition of Episcopalianism.

I do hereby declare, that $[\ldots]$ I do own the same as the confession of my faith ... which doctrine ... I am persuaded [is] founded upon the Word of God, and agreeable thereto. And I promise that, through the grace of God, I shall constantly and firmly adhere to the same, and to the utmost of my power shall in my station assert, maintain and defend the said doctrine ... ${ }^{2}$

\footnotetext{
${ }^{1}$ See for example Whitney G. Gamble, Christ and the Law: Antinomianism at the Westminster Assembly (Grand Rapids, Mich.: Reformation Heritage Books, 2018).

${ }^{2}$ Cited by Alexander C. Cheyne, "The Place of the Confession Through Three Centuries", in The Westminster Confession in the Church Today: Papers Prepared for the Church of Scotland Panel on Doctrine, ed. Alasdair I. C. Heron (Edinburgh: Saint Andrew Press, 1982), 19. For his more detailed survey see A. C. Cheyne, The Transforming of the Kirk: Victorian Scotland's Religious Revolution (Edinburgh: Saint Andrew Press, 1983), 60-87.
} 


\section{A subordinate standard}

\section{Departure de facto though not de jure}

As Alec Cheyne notes, this binding formula remained in place throughout the eighteenth century, even when Presbyterianism had become firmly established and as the intellectual climate shifted. ${ }^{3}$ With the arrival of the early Enlightenment in Scotland, we see Scottish theologians moving in very different directions. The Confession was seldom cited in the teaching of Simson and Leechman in Glasgow and (apparently) Hamilton in Edinburgh. It is clear from their work that they had travelled a long way from the theology of their covenanting forebears. The stress was on nature, reason, society, virtue, the teaching of Jesus, divine providence, and the afterlife. Little mention was made of total depravity, election, substitutionary atonement and effectual calling. The Moderates may have accentuated the limits of human knowledge and our darkened condition, but this was more the result of a natural providential order than the effects of the Fall. ${ }^{4}$ We enter a very different theological climate here.

Throughout the era of Moderate ascendancy it has generally been held that the confession retained its status largely on grounds of political expediency rather than theological commitment. According to Drummond and Bulloch, the Moderates could produce no theological work of distinction because of their attitude to the Confession. This is deeply ironic given that Moderate clergy excelled in so many other fields of study. 'They did not hold to its doctrines, but could not say so in public. ${ }^{5}$ This is confirmed by the oft-quoted remark in 1753 of John Witherspoon, who later became President of Princeton University, that 'It is a necessary part of the character of a Moderate man never to speak of the Confession but with a sneer; to give sly hints that he does not thoroughly believe it; and to make the word orthodoxy a term of contempt and reproach' ${ }^{6}$ Surveying the theological scene over two centuries, H. M. B. Reid showed how departure from the WCF was hardly a recent phenomenon.

Life in Scotland had been inexpressibly miserable for a century past. The Union with England brought brighter and more spacious thoughts. A gospel of joy, and perhaps also of self-satisfaction, grew out of improved social and educational conditions. The Prayer-Book might still declare men

\footnotetext{
${ }^{3}$ Ibid., 19-21.

${ }^{4}$ See Alexander Broadie, The Scottish Enlightenment: The Historical Age of the Historical Nation (Edinburgh: Birlinn, 2001), 113-50. Dunlop's defence of confessions in the early eighteenth century already registers a culture that is apt to treat them with 'disdain and neglect'. See William Dunlop, The Uses of Creeds and Confessions of Faith (Edinburgh, 1719), 17.

${ }^{5}$ Andrew L. Drummond and James Bulloch, The Scottish Church 1688-1843: The Age of the Moderates (Edinburgh: Saint Andrew Press, 1973), 104.

${ }^{6}$ John Witherspoon, Ecclesiastical Characteristics (Edinburgh: 1753), Maxim III, 24.
} 
to be 'miserable sinners' but the easier and more tolerant ways of the Glasgow professors told a different tale. ${ }^{7}$

Nevertheless, at the end of the Moderate era, there is a revival of enthusiasm for the WCF which must qualify this narrative. We see this in George Hill, Thomas Chalmers and in the first generation of Free Church theologians after the Disruption of 1843. Principal Cunningham's Historical Theology provides a worthy example of the confidence surrounding the entire system of doctrine contained in the Confession. Indeed, Cunningham believed it was simply a matter of time before all the churches would adhere to its tenets. In this of course he was wrong, even within Presbyterian Scotland. Throughout much of the nineteenth century, especially after about 1860 , there are serious anxieties attending the Confession and the formula of subscription. This makes the era of confessional retrenchment seem only temporary and partial.

What then were the expressed concerns about the WCF?

\section{Theological scruples}

\section{i) The civil magistrate (Chapter 23)}

Not surprisingly, the advocacy of compulsory measures in religion occasioned concern within the Secession churches in the eighteenth century. It was argued that the church must be free from the intrusion of the civil magistrate in matters spiritual - hence the principle of freedom of conscience with respect to religion became more clearly espoused. Shortly after the union of the Secession churches in 1820 a new formula was introduced which included the caveat, 'it being always understood $[\ldots]$ that we do not to approve or require an approbation of anything in those books, or in any other, which teaches, or may be thought to teach, compulsory or persecuting and intolerant principles of religion. ${ }^{8}$ This uneasiness with which those outside the established Kirk regarded the Confession's readiness to concede powers of state interference in the life of the church and the religion of the people was hardly surprising. This anxiety was similarly reflected in the USA with the result that John Witherspoon drafted new sections on the role of the civil magistrate which can still be found today in the PC(USA)'s Book of Confessions.

\footnotetext{
${ }^{7}$ H. M. B. Reid, The Divinity Professors in the University of Glasgow, 1640-1903 (Glasgow: James MacLehose, 1923), 256.

${ }^{8}$ Cited in C. G. McCrie, The Confessions of the Church of Scotland: Their Evolution in History (Edinburgh: MacNiven \& Wallace, 1907), 239.
} 


\section{ii) Election and limited atonement (Chapters $3 \& 8$ )}

The so-called doctrine of double predestination in Chapter 3 of the Confession has troubled theologians ever since Augustine was accused of introducing Manichaeism into Christian theology. While it is confessed by the WCF as a high mystery to be taught with caution, these qualifications were never quite sufficient as the literary tradition of Burns and Hogg made clear. Closely allied to these concerns was a further worry that the Confession restricted the scope of Christ's atoning work to the elect only. These were accentuated by missionary expansion in the late nineteenth century. What were missionaries to say to those outside the church who had never received the gospel? Had Christ died only for some? Did God not decree the salvation of all? Although the authors of the WCF had little express interest in Christian mission, these questions were ones of which they were aware. Election was a mystery, yet the gospel could and should be preached to all. The old formula that the death of Christ was sufficient for all, but efficient only for some, could be reconciled with several passages in the Confession.

Nevertheless, the Scottish churches in the late Victorian era craved a more explicit and unqualified declaration of the universal love of God and the comprehensive scope of Christ's atoning work. The teaching of those who had earlier been condemned, such as John McLeod Campbell and James Morison, had entered the mainstream. In the long run the heretic converted the church - so remarked Edward Caird in recalling his brother's promotion of McLeod Campbell for the DD degree at Glasgow in 1868. At any rate, this more pronounced stress on the universal love of God has been largely the default position of the Church of Scotland since the end of the nineteenth century. ${ }^{9}$

\section{iii) Adherents of other faiths (Chapter 10)}

The Confession extends extraordinary means of grace to those amongst the elect who die in infancy. The freedom of the Spirit cannot be constrained by the ordinances of the church. Yet sadly this provision is not extended to those 'not professing the Christian religion.' There is no condign merit or common grace by which they may be redeemed, no matter how well they frame their lives. This also has become a teaching firmly repudiated by the modern church.

\footnotetext{
${ }^{9}$ Edward Caird, "Memoir", in John Caird, The Fundamental Ideas of Christianity, volume I (Glasgow: Maclehose, 1899), lxxxviii.
} 


\section{iv) Biblical criticism (Chapter 1)}

William Robertson Smith was deposed from his chair in 1881 on the basis that his pursuit of historical criticism of Scripture was incompatible with what the WCF taught about the divine origin of Scripture. Smith contested this, believing it possible to adhere to both. Although he lost his case, his method of study soon prevailed. The ensuing period was one in which greater latitude was extended to biblical criticism. The Victorian divines made it clear that historical criticism, if properly applied, was no barrier to believing in the authority of Scripture. Nor did they insist upon a single reading of the text, such as a literal six days of creation.

These particular anxieties around the WCF arose at a time when a new set of theological problems, remote from those of the mid-seventeenth century, preoccupied the church. The quest of the historical Jesus, the account of human origins in Darwinian science, the task of positioning Christianity in relation to the other world religions, the rise of kenotic Christology in response to problems surrounding the two-natures formula, the challenges of scepticism and atheism, the problem of suffering, the need for a more robust social theology that distinguished the church from the kingdom of God - all these set the intellectual agenda for late nineteenth-century Christianity and they continued to be acutely felt in the period after the Great War. The WCF belonged to a different era and could not be expected to offer an adequate set of responses to new problems. Concluding his 1911 study of confessions, W. A. Curtis owned a historical perspective that had become widely held in Scotland. 'If you learn that in the Westminster Assembly a slender, or even a considerable, majority carried some particular finding only after long and anxious discussion, what are you to think of the finality or imperativeness of their injunction of it?'10

\section{A qualified commitment to the WCF}

What happened next is a familiar story with two important Declaratory Acts being passed, and a new preamble and formula of subscription being agreed. These all become integral parts of the constitution of the united Church of Scotland in 1929.

In 1879, the United Presbyterian Synod, at that time the most liberal of the three large Presbyterian blocs, passed a Declaratory Act. This asserts that the Westminster standards are of human composition and therefore imperfect. Under several headings, the Standards are affirmed but as cohering with several tenets. ${ }^{11}$

\footnotetext{
${ }^{10}$ William A. Curtis, A History of Creeds and Confessions of Faith in Christendom and Beyond (Edinburgh: T\&T Clark, 1911), 458.

${ }^{11}$ The Acts and the current formula of subscription are reproduced in Heron, The Westminster Confession in the Church Today, 141-49.
} 


\section{A subordinate standard}

1. The doctrine of redemption is consistent with God's love of 'mankind, His gift of His Son to be the propitiation for the sins of the whole world, and the free offer of salvation to men without distinction on the ground of Christ's perfect sacrifice'. These matters are 'vital in the system of Gospel truth'.

2. The doctrine of the divine decrees 'is held in connection and harmony with the truth that God is not willing that any should perish, but that all should come to repentance, and that He has provided a salvation sufficient for all'.

3. The doctrine of total depravity does not affect human responsibility under the law of God or prevent human beings from performing actions that can be considered good. (In fairness to the WCF, I cannot see that its authors would have dissented from that in any measure.)

4. ' [I]t is not required to be held that any who die in infancy are lost, or that God may not extend His grace to any who are without the pale of ordinary means, as it may seem good in His sight.'

5. The church 'disapproves of all compulsory or persecuting and intolerance principles in religion'.

6. The Gospel is to be preached to every creature. People are to provide from their 'free-will offerings' for the fulfilment of this obligation.

7. '[L]iberty of opinion is allowed on such points in the Standards, not entering into the substance of the faith, as the interpretation of the 'six days' in the Mosaic account of the creation'.

In 1892, the Free Church of Scotland passed a similar Declaratory Act, thus paving the way for the union of 1900, though resulting in a split with the departure of some into the Free Presbyterian Church. This Act likewise stresses the love of the triune God for all sinners and the responsibility of each person to repent and believe the Gospel. This is to be made known to people everywhere, though God may 'extend His mercy [...] to those who are beyond the reach of these means'. Tokens of our greatness as created in the image of God remain, people outside the faith being capable of virtuous and praiseworthy actions. The church disclaims intolerant of persecuting principles and recognises diversity of opinion 'on such points in the Confession as do not enter into the substance of the Reformed faith', the church retaining full authority to determine what falls within this description.

Both these Declaratory Acts were enshrined in the Constitution of the Church of Scotland in 1929. The liberty of opinion clause is included in the preamble and the ordinand is required to subscribe to the formula. 'I believe the fundamental 
doctrines of the Christian faith contained in the Confession of Faith of this Church.'

As an important footnote, in the aftermath of the Pope's first visit to Scotland in 1982, a further Declaratory Act was passed which detached the church from the sectarian language of the WCF. This was brought to the General Assembly by Dr Kenneth Stewart, an elder from Bridge of Allan, in 1986. The result of this measure is that the Church of Scotland has formally repudiated passages in the WCF which refer to the Pope as the antichrist and that man of perdition, to the blasphemous practice of the mass, and to the prohibition of marriage 'to infidels, papists, or other idolators'. (Chapter 24 on marriage is otherwise one of the finest in the WCF and speaks very honestly for its time about the need to recognise the remedy of divorce.)

\section{Confessional instability}

What is clear from the debates surrounding these Declaratory Acts is that the leading exponents - Cairns in the United Presbyterian Church and Rainy in the Free Church - were sincerely persuaded that the terms of the legislation were consistent with the teaching of the WCF. Others were less sure - for example, George Smeaton, a conservative theologian at New College, claimed that he could show without much difficulty that that the United Presbyterian Act was at loggerheads with the WCF. He was surely right. Admittedly, the Free Church Act is more circumspect and Rainy makes clear that it was intended 'to relieve various difficulties and scruples [...] but not to lay a new burden on anyone. ${ }^{12}$ Yet, with the benefit of hindsight, its direction of travel seems clear.

Rainy's remarks on the subject of divine predestination and sovereignty are worth considering. There are two views of truth. In the first, God is sovereign in electing a people for himself without any merit of theirs. In the second, God as Father, Son and Holy Spirit loves all of sinful humankind and his goodwill to all people is at the forefront of gospel teaching. The General Assembly, Rainy claims, was firmly of the view that both truths should be held because both are found in Scripture even though we cannot see how they agree. No-one is allowed to deny the first view of truth 'on the pretence of supporting the second'.${ }^{13}$ One problem with this is that had the authors of the Confession wished carefully to balance these two views of truth we should have found the second given greater prominence and the first denied a controlling function. The conclusion to which one is driven is that the church had entered upon a more profound dissociation

12 Robert Rainy, Explanatory Notes on the Declaratory Acts of the Free Church of Scotland (Edinburgh: 1896), 2.

${ }^{13}$ Ibid., 4. 


\section{A subordinate standard}

from its confessional standards than was conceded by either Cairns or Rainy.${ }^{14} \mathrm{It}$ is hard to resist the conclusion that neither Cairns nor Rainy had much enthusiasm for the WCF. A generation later Principal Martin would state that this way of resolving the anxieties around the Confession was less than satisfactory.

This formal dissociation of the church from the WCF in the late Victorian period may have been subtle and gradual, but its effects have been far-reaching. Since 1929, the Confession has become increasingly remote from the life, doctrine and teaching of the church. It is seldom referenced and most ministers and elders who subscribe to it have little or no knowledge of what is actually taught in the Confession. Trials for licence in which ordinands were examined by Presbytery on their knowledge of the WCF became increasingly perfunctory until these were abandoned altogether. In the Divinity Halls, the WCF ceased to be used as a point of reference and was no longer widely taught to ordinands even as an expression of seventeenth-century Reformed theology. The underlying problem is that a document written in a very different set of historical circumstances in 1646 and adhered to by only a very small minority of Christians throughout the world does not seem to capture the apostolic, catholic and ecumenical faith that has been expressed in numerous statements and reports by the General Assembly.

\section{Failure to reform}

The principal reason why the church has failed to reform its doctrinal standards is the absence of any consensus as to what would constitute an improvement. An attempt was made in the early 1970s to extend the subordinate standard of faith to include the Apostles' Creed, the Nicene Creed and the Scots Confession, thus creating a bundle of confessions that would express the church's historic faith. The substance of the faith was defined with reference to a new preamble. In my view, this attempt failed for three reasons. The first is that some on the conservative wing of the church were worried by a further liberalising of the church's theological position. The second is that on the left wing, there was a group that believed that liberty of opinion was under threat. (It may be worth recalling that the original impulse from the Presbytery of Aberdeen in the late 1960s was a fear that Bultmannian trends were corrupting the church.) A third reason is that many believed that the time was right to produce a new statement of faith, and that, until this was accomplished, no adjustment to the church's subordinate standard should be made. Agreement was almost reached in 1974 but

14 This may be confirmed by the increasing reluctance to convict Divinity professors for theological teaching which, to say the least, was in tension with the Westminster standards. 
Andrew Herron swung the whole Assembly back to the status quo. ${ }^{15}$ Even more regrettable was the proposal that a new statement of faith be produced by inviting each of the four Divinity Faculties to write a separate section. (Surely this was an act of naivete or sabotage.) What they produced was doomed to failure. Here is the first section.

The Church believes in God; but who is God? Or, perhaps, what is God? What does the word stand for? Our world finds these questions unusually difficult to answer, and it is tempted to thrust them aside. ${ }^{16}$

Perhaps this makes for good classroom material, but it is an uncertain sound of the trumpet.

In 1984, under the leadership of Professor James Torrance, the Panel on Doctrine tried again. The subordinate standard was to be extended to include four documents representing the catholic and Reformed faith of the Church of Scotland - the Apostles' Creed, the Nicene Creed, the Scots Confession and the WCF. This again commanded widespread support but more controversial was the attempt to determine the substance of the faith by reference to Declaratory Article 1. Critics such as John McIntyre were quick to point out that it had never been written for this purpose and that much of the substance of the faith was not included in it. Questions were also raised about how a bundle of different confessions could exercise a normative function in the life of the church. ${ }^{17}$ In the event, the proposals actually commanded the support of a majority of Presbyteries but not the necessary two-thirds under Barrier Act procedures. Again, an unholy alliance of the right with the left defeated the proposals. In 1985, I was the youngest member of the Panel on Doctrine and was tasked with reading through the Presbytery returns in order to summarise them for the Panel. As I recall, only one Presbytery explicitly commended the WCF - the Presbytery of Lewis. Most of the others appeared to want change, but not quite in the terms that were being proposed. At the Presbytery of Edinburgh, T. F. Torrance roundly denounced the Confession for its dangerous Nestorian tendencies - one of the milder criticisms he made of it throughout his illustrious career.

In the wake of this failure, the Panel sought permission from the General Assembly to write a contemporary statement of faith. A working party was

\footnotetext{
${ }^{15}$ For a fuller account, see Finlay A. J. Macdonald, Confidence in a Changing Church (Edinburgh: Saint Andrew Press, 2004), 168-74, and Douglas M. Murray, Freedom to Reform: The 'Articles Declaratory' of the Church of Scotland 1921 (Edinburgh: T\&T Clark, 1993), 11540.

${ }^{16}$ Church of Scotland Panel on Doctrine, "Statement of Belief for Popular Use", Reports to the General Assembly with the Legislative Acts (Edinburgh: 1976), 146.

${ }^{17}$ John McIntyre, Life and Work, November 1984, $21 \mathrm{f}$.
} 
established to carry out the task. I acted as the secretary for a few years and, as I recall, our group disagreed about most things. The composition of the group changed after Bruce McCormack and I departed New College and Dr Sheila Sedgwick took over. A statement of faith was subsequently approved by the General Assembly in 1992, not as a confessional statement but as authorised 'for use in worship and teaching. ${ }^{18}$ This statement was reproduced on the inside of the back cover of Common Order (1994), since when it has served a useful if modest purpose in the life of the Church of Scotland.

But the remit to produce a satisfactory alternative confessional position has never been discharged. This unfinished business has prompted the Presbytery of Melrose and Peebles to reopen the matter at the 2018 General Assembly. Where do we go from here?

\section{One way forward}

In my view, the principle of a bundle or book of confessions should be now revisited. This would express the catholic and Reformed identify of the church through key texts that have shaped its doctrinal position over many centuries. This has worked quite well in other churches, most notably the PC(USA) with its Book of Confessions. The inclusion of the Apostles' Creed and the Nicene Creed would be welcome, not least because these are affirmed by the Reformed confessions. The Apostles' Creed remains a useful teaching aid and it continues to be prominent in our liturgy. The Nicene Creed, as the great ecumenical symbol of the church, is one to which our church has consistently adhered, particularly in ecumenical conversations over the last century. The Scots Confession reflects the early phase of the Reformation and was the subordinate standard until 1647 - its embattled tones, its stress on divine sovereignty and its Christocentrism have frequently been commended.

There are however several problems in moving to a bundle of confessions, some more easily resolved than others. Does a bundle create confusion? Which text does one appeal to on a particular point of doctrine? Is there a lowest common denominator that constitutes the substance of the faith? ${ }^{19}$ Personally, I doubt that these are insuperable problems since the WCF itself has not exercised a normative function for a very long time. A book of confessions expresses the church's faith - one that develops under new circumstances, but which seeks to remain faithful

${ }^{18}$ Reports to the General Assembly 1992, 190.

19 See John McIntyre, "Confessions in Historical and Contemporary Setting", in The Presumption of Presence: Christ, Church and Culture in the Academy: Essays in Honour of D. W. D. Shaw, eds. Peter McEnhill and George B. Hall (Edinburgh: Scottish Academic Press, 1996), 23-40. 


\section{A subordinate standard}

to its apostolic inheritance. Situated along a timeline, these texts can reflect the consolidation, development and retrieval of the church's faith in a given place. Each generation will seek to assess and register this process; this is surely a necessary condition of ecclesial life. Admittedly, a new formula of subscription would have to be devised but we might make a virtue out of a necessity. In the PC(USA) the ordinand promises to be guided by the confessions:

Do you sincerely receive and adopt the essential tenets of the Reformed faith as expressed in the confessions of our church as authentic and reliable expositions of what Scripture leads us to believe and do, and will you be instructed and led by those confessions as you lead the people of God? $?^{20}$

Something along these lines would be more appropriate to our circumstances and might actually result in more serious attention being paid to the relevant texts by ministers and elders.

A more intractable problem concerns the oddity of having only four doctrinal standards, the last of which was composed in 1646. Is there nothing more recent that can articulate the church's faith? Are we so apathetic or latitudinarian that we cannot declare our faith anew? Or will it take a crisis in the life of the church to provide the catalyst for this process? Alternatively, is there is a risk that we will keep adding to the list of texts each time a word is required on the issue of the day?

In this connection, the biggest challenge for today's theological leadership is to identify any text that has had an important influence in the life of the church since the mid-seventeenth century. As other churches have done, we might consider the Barmen Declaration of 1934. But has it really had an impact on the Church of Scotland and does Barmen too not belong to its own time and place? My own twofold suggestion is that the church should incorporate two more recent texts to add to the bundle of four, along with a book of commentaries that would stimulate further teaching and reflection across the church. ${ }^{21}$ The two texts comprise first the aforementioned 1992 statement. Though it is not highly significant, it has received sufficient commendation and support to become the

${ }^{20}$ The Constitution of the Presbyterian Church (U.S.A.): Part II: Book of Order 2019-2021 (Louisville, Ky.: Office of the General Assembly, 2019), W-4.0404c.

${ }^{21}$ There is a happy precedent for this in the PC(USA). See Edward A. Dowey, A Commentary on the Confession of 1967 and an Introduction to the Book of Confessions (Philadelphia: Westminster Press, 1968). 


\section{A subordinate standard}

church's best attempt at a recent summary of its faith. On inspection of the first draft, Presbyteries were sceptical. Some judged that it said too much, others too little, some found it too traditional, others too liberal, and some too bland. It was criticised for being assembled by a committee which was hardly surprising. But the Panel on Doctrine took these criticisms on board and produced a version that was briefer, simpler, more rhythmic and with content that sought to unify rather than divide the church. Within its self-declared limits, I believe that it has worked surprisingly well.

The other is the 1935 statement of faith produced for the united Church of Scotland by a committee chaired by H. R. Mackintosh. ${ }^{22}$ This was based on earlier texts approved by the United Free Church in 1921 and in 1926. The impetus was the Great War and the dissociation of swathes of society from the life of the church. This statement is a serious, measured and impressive exposition of the faith, reflecting the Reformed theology that has been the dominant note in the Church of Scotland since Mackintosh's day. The 1921 text went through four printings and was translated into Czech and Spanish. The intention was to provide a more spiritually uplifting and impassioned declaration than the WCF, a statement that was more for the open-air meeting than the classroom, as Mackintosh observed.

After the union of 1929, a committee was set up under Mackintosh's convenership to draft a new statement of faith. What emerged was largely the same text as had been prepared in the United Free Church through the 1920s. A useful commentary was written by J. G. Riddell of Glasgow and published under the title of What We Believe in 1937. The statement itself had been 'cordially' commended by the General Assembly in 1935 for instruction and guidance. It was to be printed as a leaflet and included in the annual yearbook - this took place in 1936 and 1937. The drafting committee included Martin, Paterson, Donald Baillie and Burleigh, scholars of an older and younger generation who were leading figures in the twentieth-century Kirk. Given its history and the terms in which it was approved following Presbyterian reunion, it seems a promising candidate today for inclusion in a Book of Confessions. The 1935 statement is trinitarian, Christocentric, sacramental, ecumenical, and engaged with the more critical social theology that had emerged in the churches by the early twentieth century. It also includes a separate chapter on the Spirit and has a stronger missional impetus, both of which are lacunae in the WCF. Although it seems to have disappeared from view in the late 1930s - the preparation of the 1940 Book of Common Order

\footnotetext{
${ }^{22}$ In much of what follows, I am indebted to an unpublished essay by Craig Meek, Edinburgh $\mathrm{PhD}$ student. His research work on Mackintosh is likely to shed further light on this material.
} 
with its publication of the Apostles' Creed and Nicene Creed may have been a factor here - in its day, it commanded widespread support.

\section{Renewed appreciation of the WCF}

The legal status of the WCF has prevented us for too long from viewing it in its historical context as a document of its time. But once we do this, we find that there are many features that deserve our admiration. Produced by a committee, it exhibits a surprising consistency. Clear in its exposition, it is not difficult to follow. As befits the Reformed tradition, it is practical in intent and shuns pointless speculation. The felicity of its language offers some striking expressions - Christ is anointed by the Holy Spirit without measure. Its intellectual rigour and temperate style are broken only occasionally by vituperative language. In an age of emoting, soundbites and anti-intellectual tendencies, it is a summons to deeper reflection and rigorous exploration of the faith. With a better positioning within a Book of Confessions, we might return to it again in a spirit of curiosity and respect. And if in the end we must part company with much of its theology, we should so through dialogue, appreciation and a careful contextualising of its material. In re-engaging with our confessional past, we should be cautioned by John Tulloch's observation that the 'worst preparation for confronting any great conflict that may be awaiting the church is ignorance or indifference'. ${ }^{23}$

David Fergusson is Professor of Divinity at the University of Edinburgh.

${ }^{23}$ Margaret Oliphant, A Memoir of the Life of John Tulloch (Edinburgh: Blackwood, 1888), 221. 